\title{
Effect of Recognition and Career Advancement on Employee Job Performance: A Study of Nigerian Brewery Plc. Imagbon, Ijebu- Ode, Ogun State
}

Michael Oluseye Afolabi (Corresponding Author), Adebolaji Ekong Essien, Modupe Omowunmi Ogunsola

Department of Business Administration

Gateway (ICT) Polytechnic, Saapapde, Ogun State, Nigeria

E-mail: michael.afolabi@gaposa.edu.ng

Received: June 21, 2021 Accepted: January 14, 2022 Published: January 15, 20222

doi:10.5296/bms.v13i1.19468ＵRL: https://doi.org/10.5296/bms.v13i1.19468

\begin{abstract}
The purpose of this study is to explore the effect of recognition and career advancement on employee job performance in Nigeria Brewery Plc in Imagbon, Ijebu Ode, Ogun State. Survey research design was adopted for the study. The target population consists of 215 staff of Nigerian Brewery Plc. Imagbon, and sample size was 88. A structured questionnaire was used as a research instrument in gathering the primary data used for the study. The data collected were analyzed using mean, standard deviation and correlation analysis with the help of Statistical Package for Social Science (SPSS version 23). The results and findings indicated that employee recognition ( $\mathrm{r}-0.759$, p- 0.029) and career advancement ( $\mathrm{r}-0.594$, p0.012) have significant and positive effects on employee job performance in Nigerian Brewery Plc Imagbon, Ijebu Ode, Ogun State. The research recommends that the management of Nigerian brewery Plc should put a measure in place to ensure retention of younger employees that constitute the greater percentage of the brewery industry through adequate employee recognition programmes; and that management should be fully committed to employee flexible work schedule and provide an enabling environment for all and sundry within the organization.
\end{abstract}

Keywords: motivation, employee recognition, career development, performance, employee job performance 


\section{Introduction}

It has often been said that the most important asset of any organization through which it achieves competitive advantage is its employees. This is true because the key element of an organization is not a building or a set of policies and procedures; but people and their relationships with one another. An organization exists when people interact with one another to perform essential functions that help attain goals (Daft, 2010). The so-called workforce is the major determinant factor of the organization performance (Kakui, and Gachunga, 2016). For employee to be more productive in their services to the organization, the need for motivation cannot be over-flogged. It is believed that motivated employees are more likely to stay and help build the firm which will in turn reduce the cost of recruitment and training (Omollo, 2015). Various research studies have shown that the success and survival of organizations, as well as the accomplishments and performance of the organizations, are determined by the way the workers are motivated (Aarabi, Subramaniam andAkeel, 2013; Zirra, Mambula and Anyatonwu, 2019). Motivation in organizations is perfectly vital and needed because it could change and improve the performance of workers in affirmative manner. Motivation remains an internal drive to satisfy an unsatisfied need of the employees and to achieve a certain goal within the organization (Ongalo and Tari, 2015).

One of the business organization objectives is to gain competitive advantage and to make profit. Without the employees discharging their assigned responsibilities, the objectives of the organizations may not be achieved easily and timely. Thus, employee performance is a crucial determinant of organizational goals (Olajide, Okunbanjo and Adeoye, 2016). Every organization would desire the workforce that has a good performance and this is mostly achieved through effective motivation. An employee may be motivated through financial or non-financial incentives. Financial incentives are the monetary benefits provided to an employee in the form of higher pay, bonus, commission etc., Non-financial incentives are the non-monetary benefits such as greater decision-making authority, better designation, career advancement opportunities, job recognition, good working environment, and so on. This research study focuses on effect of recognition and career development as motivational tools on employee job performance.

The capability of organizations to attain greater heights and have a sustainable competitive advantage depends greatly on the performance of their workers. In their attempt to motivate employees to achieve high performance, organizations often placed emphasis on financial rewards at the expense of non-financial rewards (Amoatemaa and Kyeremeh, 2016). However, considerable basic research has shown that though financial rewards positively reinforce performance-enhancing behaviours and satisfy employees to some extent, but for committed employees, recognition must be given to keep them motivated, appreciated and committed (Luthans, 2000; Danish and Usman, 2010). It is believed that employees do not only want attractive pay and benefits, but also expect that their efforts are valued, appreciated and treated fairly (Akafo, and Boateng, 2015). It is against these backdrops that this study examines the effects of recognition and career advancement in relations with employee job 
performance that have not been studied in Nigeria particularly with respect to alcoholicbeverages industry in Nigeria. Thus, the present study is an attempt to bridge this identified gap. The objective of this study therefore is to evaluate the effect of employee recognition on employee job performance in Nigerian Brewery Plc. and as well find-out the influence of career development on employee job performance in Nigerian Brewery Plc.

\section{Literature Review and Hypotheses Development}

\section{Concept of Employee Recognition}

Employees do not only want attractive pay and benefits, but also expect that their efforts are valued, appreciated and treated fairly (Peter and Boateng, 2015). Recognition is the timely, informal or formal acknowledgement of a person's or team's behaviour, effort or business result that supports the organization's goals and values, and which usually is beyond normal expectations (Harrison, 2011). It is the acknowledgement, appreciation, or approval of the positive accomplishments or behaviours of an individual or team (Caligiuri; Lepak; and Bonache 2010; Nelson, 2005; University of IOWA, 2009). It also encompasses praise or a personal note of acknowledging achievements including small gestures that are important to employees (Gostick and Elton, 2007). This recognition could be in forms of personal recognition, achievement recognition, work performance recognition; and recognition of dedication on the part of the workers (Brun and Dugas, 2008).

Employee recognition is regarded as important tool in promoting workers' motivation and organizational success (Tessema1; Ready; and Embaye, 2013). This is because workers are likely to be motivated to improve their performance based on recognition, and are likely to be less motivated if organization neglects their contributions (Robbins and Coulter, 2002; Shonubi; Abdullah; Hashim; and Hamid, 2016).

Ho1:Recognition has no significant effect on the job performance of employee in the Nigerian Brewery Plc.

\section{Concept of Career and Career Development}

Career refers to series of positions occupied by an individual throughout his or her lifespan (Robbins and Coulter, 2002). It describes the constant progress, experience and skill acquisition of a person in a specific work field. Career development, on the other hand, is a lifetime process through which organization's workforce is being managed within organization or between the organizations especially in the area of their work experience (Ikechukwu and Paschal, 2017). According to Armstrong (2009), career development is a lifelong process involving managing learning, work, leisure, and transitions in order to move toward a personally determined and evolving preferred future. Rival and Sagala (2009) opined that career development is the process of improving the ability of individual work accomplished in order to achieve the desired career. According to Ikechukwu and Paschal (2017), career development covers an employee's working life which starts with staff orientation, on-job training, experience, short courses, professional courses, post graduate degrees or diplomas. 
Ho2:Career development has no positive effect on the job performance of an employee in the Nigerian Brewery Plc.

\section{Employee Job Performance}

The vital resource to any organization is its workforce. They have a regular role to play which comprises of the organization's success which cannot be underestimated (Kakui and Gachunga, 2016). Performance is basically what employees do or do not do on their job. Employee job performance involves quality and quantity of output, presence at work, accommodative and helpful nature and timeliness of output (Shahzadi, et el., 2014). Performance can be defined as "the achievement of specific tasks measured against predetermined or identified standards of accuracy, completeness, cost and speed" (DeCenzo and Robbins, 2010). It is the result of work produced by employees who appear in accordance with its role in the organization.

\section{Methodology}

Survey method was adopted in carrying out this study. A survey research design can be used when a researcher seeks to observe, assess and examine many variables at a point in time. Survey research was applied to this study as a result of the need to generate primary data to achieve the research objectives. The survey research design is appropriate because all the variables of the study were observed at a point in time, and research design saves cost. Also, the survey design gives the researcher opportunity to make predictions about the relationships between certain variables. The population of this study was made up of all the employees in the Nigeria Brewery Plc. Imagbon, Epe Road, Ijebu Ode, Ogun State with a total population of 124 as stated in the 2015 annual report. A sample of 90 staff from Nigerian Brewery Plc. was randomly selected. A structured questionnaire was adopted and used for data collection. The questionnaire contained biographical, recognition, career advancement and employee job performance questionnaires. The biographical questionnaire contained the personal information of the respondents: sex, age range, educational qualifications, marital status, departments, and tenure. The questionnaire consisted of items related to employee recognition, career advancement and employee job performance questionnaires.

Two human resources specialists validated the instrument and a reliability test using test-retest method yielded a correlation of 0.85.Questionnaires were administered to 90 staffs. 88 copies of the questionnaires were received back and thus the return percentage was 95.56\%. The questionnaire was self-administered. Statistical Package for Social Sciences (SPSS) version 23 was adopted for the analysis of the data gathered through the questionnaire. The statistical methods consisted of descriptive (mean and standard deviation) and inferential statistics (Linear regression).

\section{Results and Discussion}

Table 1 shows, the total numbers of male respondents are 70 representing $79.55 \%$, while the remaining $18(20.45 \%)$ are females. Therefore, the majority of the respondents are male 
which confirms the facts that brewery jobs are considered to be more suitable for male. In respect to the age distribution of respondents, the table indicates that $17(19.32 \%)$, $48(54.55 \%), 19(21.59 \%)$ and $4(4.54 \%)$ are within the age brackets of 20 - 29 years, $30-39$ years, 40 - 49 years and 50 years \& above respectively. This implies that majority of the respondents fall within the economic active age group as in summary, a total of 84 representing $95.46 \%$ of the respondents, going by the analysis, fall within $20-49$ years.

Furthermore, the analysis reveals that $34(38.64 \%)$ of the respondents are single, and the remaining 54(61.36\%) are married. This indicates that there are more married workers in Nigerian Brewery Plc compared to single. The survey also revealed that among the respondents, $8(9.09 \%)$ had completed secondary education, 42(47.73\%) had NCE/ND certificate, 26(29.54\%) had HND and bachelor degrees, $8(9.09 \%)$ had master's degree, while $4(5.45 \%)$ had professional certificates. This shows that bulk of the respondents, $(77.27 \%)$ had NCE/ND certificate \& HND/Bachelor degrees. This implies that majority of the respondents are enlightened to provide adequate response to the questions in the research instrument.

The analysis shows that, 5(5.68\%) are in the cadre of middle manager, $27(30.68 \%)$ are within the level of supervisory manager and 56(63.64\%) constitute other lower positions (factory workers) in the Nigeria Brewery Plc. The study reveals that majority of the respondents are within the lower level management and factory workers' positions. In analyzing the respondents base on employment contract, the table indicates that $45(51.14 \%)$ are permanent staff, $3(3.41 \%)$ are contract staff and the remaining $40(45.45 \%)$ are casual workers. Furthermore, the demographic analyses of the respondents on the basis of the department they belong were also reported in Table 1 .

In addition, the study analyzed the demographic factors based on the work experience in the alcoholic- beverage industry. Among the respondents, 56(63.64\%), 27(30.68\%), and 5(5.68\%) have spent 1-5, 6-10, and 11-15 years in the services of Nigerian Brewery Plc respectively. The analysis indicates that larger percentage $(94.32 \%)$, of the respondents have spent between 1- 10 years in the service of Nigerian Brewery Plc. 
Table 1. Demographic data of the Respondents

\begin{tabular}{|c|c|c|}
\hline Item & Frequency & Percentage $(\%)$ \\
\hline \multicolumn{3}{|l|}{ Sex } \\
\hline Male & 70 & 79.55 \\
\hline Female & 18 & 20.45 \\
\hline Total & 88 & 100 \\
\hline \multicolumn{3}{|l|}{ Age Bracket } \\
\hline 20-29years & 17 & 19.32 \\
\hline 30-39years & 48 & 54.55 \\
\hline 40-49years & 19 & 21.59 \\
\hline 50years \& above & 4 & 4.54 \\
\hline Total & 88 & 100 \\
\hline \multicolumn{3}{|l|}{ Marital Status } \\
\hline Single & 34 & 38.64 \\
\hline Married & 54 & 61.36 \\
\hline Widow (er) & - & - \\
\hline Seperated & - & - \\
\hline Total & 88 & 100 \\
\hline \multicolumn{3}{|l|}{ Educational Qualification } \\
\hline SSC/WASSC/GCE O level & 8 & 9.09 \\
\hline $\mathrm{ND} / \mathrm{NCE}$ & 46 & 47.73 \\
\hline Bachelor's Degree/HND & 26 & 29.54 \\
\hline Master Degree & 8 & 9.09 \\
\hline
\end{tabular}


Total

Status

Top Management Level

Middle Management Level

Total

Nature of Employment

Permanent

Temporary

Contract

Casual

Total

88

\section{Work Experience}

1-5years

16-20years

Above 20years

Total

88

100

Source: Field survey, 2019 


\section{Mean and Standard deviation Results}

From the table 2 below, the respondents agreed that they normally receive regular praise for work done $(\pi=2.95)$, that they also receive praise for every task they perform with good output $(\pi=2.97)$; and few, less than average of the respondents, claimed they always get credit for job well done $(\pi=2.44)$. Furthermore, the researcher observed form the analysis that respondents agreed that their progress are always acknowledged in Nigerian Brewery Plc $(\pi=3.34)$; and hard-work recognized $(\pi=3.42)$. They also agreed that Nigerian brewery Plc cares about appreciating her employees $(\pi=3.96)$. Additional respondents agreed that job recognition boosts their morale towards increased performance (mean $=4.56$ ); and motivates them towards improved performance $(\pi=4.52)$.

Table 2. Response to Questions on Employee Recognition

\begin{tabular}{lrrrl}
\hline \multicolumn{1}{c}{ Statement } & $\mathbf{N}$ & $\begin{array}{c}\text { Mean } \\
(\boldsymbol{\pi})\end{array}$ & $\begin{array}{c}\text { Std. } \\
\text { Dev. }\end{array}$ & Remark \\
\hline I am praised regularly for my work & 88 & 2.95 & 0.74 & Good \\
I receive praise for every task I perform with good output. & 88 & 2.97 & 0.74 & Good \\
I always get credit for job well done. & 88 & 2.44 & 1.18 & Poor \\
I am told that I am making progress. & 88 & 3.34 & 1.17 & Good \\
My hardwork is always recognized. & 88 & 3.42 & 1.00 & Good \\
My company cares about appreciating her employees. & 88 & 3.96 & 1.24 & Good \\
Job recognition boosts my morale towards increased & 88 & 4.56 & 0.49 & Good \\
performance. & 88 & 4.52 & 0.50 & Good \\
Job recognition motivates me towards improved performance. & 88 & & & \\
Valid N (listwise) & & & & \\
\hline
\end{tabular}

\section{Source: SPSS Computation (2019)}

From table 3 below, it could be deduced that career development enhances employees' job performance in Nigeria brewery Plc. From the analysis, the researcher observed that the respondents generally agreed that employees are provided with opportunities to better their personal career in Nigerian brewery Plc $(\pi=4.32)$, that the firm has a systematic program that identifies and develops employee skills $(\pi=4.03)$; and that the company is quick in implementing solutions that better their skills $(\pi=4.45)$. The study's analysis equally reveals that the respondents agreed that in-house training enhances employees' dedication to job performance $(\pi=4.39)$ in Nigerian brewery Plc; that the organization adopted new strategies to improve employees' efficiency $(\pi=4.54)$; the employees receive regular development through workshops $(\pi=3.73)$; and that employees' skills match their responsibilities and also enhance their performance $(\pi=4.36)$.

Table 3. Response to Questions on Career Development

\begin{tabular}{lcccc}
\hline Statement & $\mathbf{N}$ & $\begin{array}{c}\text { Mean } \\
(\boldsymbol{\pi})\end{array}$ & $\begin{array}{c}\text { Std. } \\
\text { Dev. }\end{array}$ & Remark \\
\hline $\begin{array}{l}\text { The organization provides opportunities that encourage me to } \\
\text { better my services. }\end{array}$ & 48.51 & 0.50 & Good \\
$\begin{array}{l}\text { The company provides opportunities to better my personal } \\
\text { career. }\end{array}$ & 88 & 4.32 & 0.79 & Good \\
The firm has a systematic program that identifies and develops & 88 & 4.03 & 1.06 & Good \\
\hline
\end{tabular}


employee skills.

The company is quick in implementing solutions that better my skills

In house training enhances my dedication to job performance.

My organization adopted new strategies to improve efficiency.

I receive regular development through workshops.

My skills match my responsibilities and also enhance my performance.

Valid N (listwise)

Good

$\begin{array}{lll}88 & 4.45 \quad 0.96\end{array}$

$4.39 \quad 0.49$

$4.54 \quad 0.50$

$3.73 \quad 0.97$

$4.36 \quad 0.48$

Good

Good

Good

Good

\section{Source: SPSS Computation (2019)}

Regarding employee job performance in Nigerian brewery Plc, the respondents agreed that their performance became higher in spite of not being recognized for past achievement ( $\pi=$ 2.76), they fairly agreed that their level of creativity, consistency and work performance increase despite not been delegated to carry out leadership role $(\pi=2.67)$. The analysis revealed that respondents agreed that their service quality are not affected despite non-advancement of their career $(\pi=2.87)$. Further, they disagreed to continuous hard-work and maintenance of efficiency inspite of non- acknowledgement of job well done $(\pi=2.26)$. The respondents equally agreed that they doubled their levels of performance despite lack of delegation of responsibility to them $(\pi=2.51)$; and that their task proficiency level increases whenever they are rewarded for past efficient services $(\pi=2.65)$. It was also observed that respondents agreed that quality of work helps in enhancing performance on the job $(\pi=4.61)$; and that adequate training development programmes boost their morale, hence leads to increase job performance $(\pi=4.60)$.

Table 4. Response to Questions on Employee Performance

\begin{tabular}{|c|c|c|c|c|}
\hline Statement & $\mathbf{N}$ & $\begin{array}{c}\text { Mean } \\
(\pi)\end{array}$ & $\begin{array}{l}\text { Std. } \\
\text { Dev. }\end{array}$ & Remark \\
\hline $\begin{array}{l}\text { My performance became higher in spite of not being } \\
\text { recognized for past achievement. }\end{array}$ & 88 & 2.76 & 0.52 & Good \\
\hline $\begin{array}{l}\text { My level of creativity, consistency and work performance } \\
\text { increase despite not been delegated to carry out leadership role. }\end{array}$ & 88 & 2.67 & 0.51 & Good \\
\hline $\begin{array}{l}\text { My service quality is not affected despite my career that is not } \\
\text { advanced. }\end{array}$ & 88 & 2.87 & 0.33 & Poor \\
\hline $\begin{array}{l}\text { I still work hard and maintain my efficiency inspite of not } \\
\text { being acknowledged for job well done. }\end{array}$ & 88 & 2.26 & 0.44 & Poor \\
\hline $\begin{array}{l}\text { I doubled my level of job performance despite } \\
\text { lack of delegation of responsibility to me. }\end{array}$ & 88 & 2.51 & 0.50 & Good \\
\hline $\begin{array}{l}\text { My task proficiency level increases whenever I am rewarded } \\
\text { specially for past efficient services. }\end{array}$ & 88 & 2.65 & 0.47 & Good \\
\hline Quality of work helps in enhancing my performance on the job. & 88 & 4.61 & 0.48 & Good \\
\hline $\begin{array}{l}\text { Adequate training and development programmes boost my } \\
\text { morale, hence leads to increase job performance. }\end{array}$ & 88 & 4.60 & 0.49 & Good \\
\hline Valid N (listwise) & 88 & & & \\
\hline
\end{tabular}

Source: SPSS Computation (2019) 


\section{Testing of Hypothesis and Discussion of Findings}

The result shows that the relationship between employee recognition and employee job performance that is $p$-value which is 0.029 which is less than significant level $(\mathrm{p}<0$.05) and co-efficient (r) value is 0.759 (75.9\%). It shows that $\mathrm{H} 0$ is rejected and hence $\mathrm{H} 1$ is accepted. Therefore, employee recognition has positive effect ( $\mathrm{r}-0.759$, $\mathrm{p}-0.029)$ on employee job performance in Nigeria Brewery Plc. In other words, increase in employee recognition will simultaneously increase employee job performance. The result also reveals that career advancement has positive influence ( $\mathrm{r}-0.594, \mathrm{p}-0.012)$ on employee job performance in Nigeria Brewery Plc. The shows that $\mathrm{H}_{0}$ is rejected and hence $\mathrm{H} 1$ is accepted. Therefore, career advancement has positive effect ( $r-0.594$, p- 0.012) on employee job performance in Nigeria Brewery Plc. In other words, increase in career advancement will simultaneously increase employee job performance.

Table 5. Correlation Result

\begin{tabular}{llcc}
\hline & & Recognition & Career advancement \\
\hline Employee job performance & Pearson correlation & 0.759 & 0.594 \\
& Sig. (two tailed) & .029 & .012 \\
& $\mathbf{N}$ & $\mathbf{8 8}$ & $\mathbf{8 8}$ \\
\hline
\end{tabular}

\section{Source: SPSS Author's Calculation}

\section{Discussion}

Considering the result of the first hypothesis, it shows that employee recognition has positive effect on employee job performance in Nigeria Brewery Plc. This is in line with the conclusion of the study conducted by Baskar in 2015 on the impact of rewards and recognition on employee motivation. The study found out significant relationship between motivation to perform better and the recognition workers received. It was discovered that employees put extra effort in order to achieve a reward or recognition in their company. The result also support the study conducted by Ndungu (2017) on the effect of rewards and recognition on employee performance in public educational institutions, it was found-out that recognition rewards affected employees' performance as there was a significant relationship between recognition rewards and employee performance. The result of the second hypothesis shows that career development has influence on the job performance of employees in Nigerian Brewery Plc. This result is in support of the study carried- out by Ikechukwu and Pascal, (2017) which pointed out that career development has significant influence on employee performance. It proves that career development has significant influence on the increase in employee performance because career development which is managed well by a company will provide good spirit for its employees to achieve their expected careers by increasing their motivation. In other words, the better the career development in a certain company, the better the employee performance in the company (Mark and Nzulwa, 2018). 


\section{Conclusion and Recommendations}

The present study investigated effect of recognition and career advancement on employee job performance in Nigerian Brewery Plc. The study findings enabled the researchers make various conclusions. Firstly, the researcher concluded that employee recognition has a significant effect on the performance of employees in Nigerian brewery Plc. The findings established positive relationship between employee recognition and the performance of employees in Nigerian brewery Plc. Secondly, the researcher concluded that career development has a significant effect on the job performance of an employee in the Nigerian Brewery Plc. The findings established positive relationship between career development and employees' performance in Nigerian brewery Plc. The management of Nigerian brewery Plc should put a measure in place to ensure retention of younger employee that constitutes the greater percentage of the brewery industry through adequate employee recognition programmes. This will invariably reduce intention to quit, commitment will be high and performance will improve. Attention should be given to improving on giving credit for job well done by the employees (acknowledging employees' good performance). This may enhance dedication to work and or trigger future greater performance. Management should be fully committed to employee career advancement (employee education in particular) especially among lower level management staff. This will not only improve performance, boost morale, but also helps in organization succession planning.

\section{References}

Aarabi, M. S., Subramaniam, I. D., \& Akeel, A. B. (2013). Relationship between Motivational Factors and Job Performance of Employees in Malaysian Service Industry. Canadian Center of Science and Education, Asian Social Science, 9(9), 1911-2025. https://doi.org/10.5539/ass.v9n9p301

Akafo, V., \& Boateng, P. A. (2015). Impact of Reward and Recognition on Job Satisfaction and Motivation. European Journal of Business and Management, 7(24), 112-124.

Amoatemaa, A. S., \& Kyeremeh, D. D. (2016). Making Employee Recognition a Tool for Achieving Improved Performance: Implication for Ghanaian Universities. Journal of Education and Practice, 7(34), 46-52.

Armstrong, M. (2009). Armstrong's Handbook of Human Resource Management Practice. $11^{\text {th }}$ Edition, London, Philadelphia.

Baskar, P. R. (2015). A Study on the Impact of Rewards and Recognition on Employee Motivation. International Journal of Science and Research, 4(11), 1644-1648. https://doi.org/10.21275/v4i11.NOV151549

Brun, J., \& Dugas, N. (2008). An analysis of Employee Recognition: Perspectives on Human Resources Practices. The International Journal of Human Resource Management, 19(4), 716-730. https://doi.org/10.1080/09585190801953723 
Byars \& Rue (2004). Human Resource Management, McGraw-Hill, Irwin.

Caligiuri, P., Lepak, D., \& Bonache, J. (2010). Global Dimensions of Human Resources Management: Managing the Global Workforce, John Wiley and Sons Inc, Hoboken, NJ.

Daft, R. L. (2010). Organization theory and design, $10^{\text {th }}$ edition, South- western: Cent Learning.

Danish, R. Q., \& Usman, A. (2010). Impact of reward and recognition on job satisfaction and motivation: An empirical study from Pakistan. International Journal of Business and Management, 5(2), 159. https://doi.org/10.5539/ijbm.v5n2p159

DeCenzo, D. A., \& Robbins, S. P. (2010). Fundamentals of Human Resource Management, $10^{\text {th }}$ Edition, Hoboken, NJ: John Wiley andSons, Inc.

Gostick, A., \& Elton, C. (2007). The Daily Carrot Principle: 365 Ways to Enhance Your Career and Life, New York: Simon and Schuster.

Harrison (2011). retrieved from recognition reward.blobspot.com on (19/09/2011).

Ikechukwu, D., \& Paschal, A. J. N. (2017). Effects of Career Growth on Employees Performance: A Study of Non-Academic Staff of Michael Okpara University of Agriculture, Umudike, Abia State, Nigeria. World Journal of Entrepreneurial Development Studies, 1(1), $100-111$.

Kakui, I. M., \& Gachunga, H. (2016). Effects of Career Development on Employee Performance in the Public Sector: A Case of National Cereals and Produce Board. The strategic Journal of Business and Change Management, 3(3), 308-324.

Luthans, K. (2000). Recognition: A powerful but often overlooked leadership tool to improve employee performance. Journal of Leadership Studies, 7(1).

https://doi.org/10.1177/107179190000700104

Mark, L., \& Nzulwa, J. (2018). Effect of Career Development Programs on Employee Performance in Kenya. A case of National Hospital Insurance Fund. International Journal of Social Sciences and Information Technology, IV(V), 693-709.

Nasution, F. N., Mariatin, E., \& Zahreni, S. (2018). The Influence of Career Development and Organizational Culture on Employee Performance. International Journal of Scientific Research and Management, 6(1), 57-65. https://doi.org/10.18535/ijsrm/v6i1.el09

Ndungu, D. N. (2017). The Effects of Rewards and Recognition on Employee Performance in Public Educational Institutions: A Case of Kenyatta University, Kenya. Global Journal of Management and Business Research, 17(1)1.

Nelson, B. (2005). 1001 Ways to Reward Employees, 2nd Edition, New York: Workman Publishing.

Olajide, O. T., Okunbanjo, O. I., \& Adeoye, A. O. (2016). Delegation of Authority and 
Employee Performance: An Empirical Evidence from Ikeja Division in Lagos State, Journal of Business Administration, 6(8), 103-110.

Omollo, P. A. (2015). Effect of motivation on employee performance of commercial banks in Kenya: A case study of Kenya Commercial Bank in Migori County. International Journal of Human Resource Studies, 5(2). https://doi.org/10.5296/ijhrs.v5i2.7504

Ongalo, E. A., \& Tari, J. (2015). Effect of Employee Motivation Strategies on Organizational Performance: A Case of Electricity Generating and Distribution Firms in Kenya. European Journal of Business and Management, 7(8), 55-65.

Osibanjo, A. O., Oyewunmi, A. E., \& Ojo, S. I. (2014). Career Development as a Determinant of Organizational Growth: Modelling the Relationship between these Constructs in the Nigerian Banking Industry. American International Journal of Social Science, 3(7), 67-76.

Rehman, S. (2017). Impact of Career development on Organizational Commitment. International Journal of Business and Administrative Studies, 3(3), 100-111. https://doi.org/10.20469/ijbas.3.10003-3

Robbins, S. P., \& Coulter, M. (2002). Management, 7th Edition, Prentice Hall.

Shahzadi, I., Javed, A., Pirzada, Nasreen, S., \& Khanam, F. (2014). Impact of Employee Motivation on Employee Performance. European Journal of Business and Management, 6(23), 159-166.

Sharma, P. (2016). Theories of Career Development: Educational and Counseling Implications. International Journal of Indian Psychology, 3(4), No. 63. https://doi.org/10.25215/0304.116

Shonubi, O. A., Abdullah, N., Hashim, R., \& Hamid, N. (2016). Recognition and Appreciation and its Psychological Effect on Job Satisfaction and Performance in a Malaysia IT Company: Systematic Review. Journal of Humanities and Social Science, 11(21), 5222-5227. https://doi.org/10.9790/0837-2109064755

Tessema1, M. T., Ready, K. J., \& Embaye, A. B. (2013). The Effects of Employee Recognition, Pay, and Benefits on Job Satisfaction: Cross Country Evidence. Journal of Business and Economics, 4(1), 1-12.

University of IOWA (2009) Reward \& Recognition, available online at: http://research.uiowa.edu/pimgr/?get=reward

Zirra, C. T. O., Mambula, C. J., \& Anyatonwu, P. (2019). Impact of Fringe Benefits on Employee Performance: A Study of NASCO Group, Jos Plateau State. International Journal of Education and Social Science, 6(1). 


\section{Copyright}

Copyright for this article is retained by the author(s), with first publication rights granted to the journal.

This is an open-access article distributed under the terms and conditions of the Creative Commons Attribution license (http://creativecommons.org/licenses/by/4.0/). 